\title{
WHY INDONESIA SHOULD DEVELOP TUNA SEA FARMING TO OVERCOME OVERFISHING? A REVIEW OF TWO SIDES ARGUMENT
}

\author{
*Maharani Yulisti, Rizky Muhartono and Armen Zulham \\ Balai Besar Penelitian Sosial Ekonomi Kelautan dan Perikanan \\ Gedung Balitbang KP I Lt. 4 \\ Jalan Pasir Putih Nomor 1 Ancol Timur, Jakarta Utara \\ Telp: (021) 64711583 Fax: 64700924 \\ *email: maharani2811@yahoo.com \\ Diterima 13 Juni 2014- Disetujui 2 Nopember 2014
}

\begin{abstract}
ABSTRAK
Tuna is the mainstay of fisheries export commodities in Indonesia with a total export amounted to 201.159 tons and export value of 750 million dollars in 2012. The high demand tuna improve the practice of tuna captured in the sea, causing a decline in tuna stocks both in the number and size of tuna caught. This condition triggers the experts to culture tuna in laboratory scale to reduce the impact of overexploitation (overfishing). However, the tuna sea farming is under the spotlight because in practice, some countries do tuna farming without hatching of the parent tuna but merely enlarge a baby tuna are caught from the wild to market size. This gives rise to a difference of opinion of many experts on tuna farming practices. Therefore, this article highlights the pros and cons of experts on tuna farming from environmental, economic and technical, to determine whether Indonesia needs to develop tuna farming to cope with overfishing. The method used in this research is the study of literature writings on tuna farming and analyzed descriptively. Results of the analysis showed that despite the many negative opinions about the tuna sea farming, the Indonesian government should support the of tuna sea farming with tuna breeding research, as has been done by the Research Institute for Marine Fisheries Gondol. If the tuna breeding is successful, will have a great impact on the problems of the world tuna demand which increasing every year.
\end{abstract}

Keywords : tuna, sea farming, overfishing, review

Abstrak : Mengapa Indonesia harus Mengembangkan Budidaya Tuna untuk Mengatasi Penangkapan Berlebih? Sebuah Review Argumen dari Dua Sisi oleh : Maharani Yulisti, Rizky Muhartono and Armen Zulham

Tuna merupakan komoditi export perikanan andalan di Indonesia dengan jumlah export sebesar 201,159 ton dan nilai export 750 juta dolar pada tahun 2012. Permintaan tuna yang tinggi meningkatkan praktek penangkapan tuna di laut, menyebabkan turunnya stok tuna baik dari sisi jumlah maupun ukuran tuna yang tertangkap. Hal ini memicu para ahli untuk membudidayakan tuna di kandang maupun skala laboratorium untuk mengurangi dampak tangkap lebih (overfishing). Namun, usaha pembudidayaan tuna ini mendapat sorotan karena pada prakteknya beberapa negara melakukan budidaya tuna tanpa melakukan penetasan dari induk tuna melainkan hanya membesarkan bayi tuna yang ditangkap dari alam sampai dengan ukuran ikan yang diharapkan oleh pasar. Hal ini menimbulkan perbedaan pendapat dari banyak ahli mengenai praktek budidaya tuna. Oleh karena itu, artikel ini menyoroti tentang pro dan kontra dari para ahli mengenai budidaya tuna dari aspek lingkungan, ekonomi dan tekniknya, untuk mengetahui apakah Indonesia perlu mengembangkan budidaya tuna untuk mengatasi overfishing. Metode yang digunakan dalam penelitian ini adalah dengan studi literature tulisan-tulisan mengenai budidaya tuna dan dianalisis secara deskriptif. Hasil analisis didapatkan bahwa meskipun dengan banyak pendapat negatif mengenai budidaya tuna, sebaiknya pemerintah Indonesia mendukung pembudidayaan tuna melalui penelitian pengembangbiakan tuna, seperti yang telah dilakukan oleh Balai Besar Penelitian Perikanan Laut Gondol. Apabila pengembangbiakan tuna berhasil, akan memberikan dampak yang besar terhadap permasalahan permintaan tuna dunia yang meningkat setiap tahunnya.

Kata kunci: : tuna, budidaya laut, tangkap lebih, review

\section{INTRODUCTION}

Tuna is one of the most tradable seafood commodities in the world. Indonesian Tuna products contribute about $9 \%$ of export value to the world trade of fisheries products and the demand of special tuna products in the world is still increasing, with Japan, USA and some European countries as the main market (FAO, 2014). High demand on its products makes Tuna's price becoming expensive. Tuna is utilized for being tuna canned, dried, frozen and fresh, namely sushi.
Consumption of tuna has increased in recent decades. The Organization for the Promotion of Responsible Tuna Fisheries (OPRT) mention that, tuna consumption was increased from 900,000 tonnes in 1975 to 1.9 million tonnes in 2001. However, since last decade consumption of Tunnas decreased from 2.3 million tonnes in 2004 to 2.06 million tonnes in 2006 and continued declined to 1.97 million tonnes in 2009. OPRT also mentions that Japanese people consumed nearly a quarter of world tuna products, wich consist of sashimi (21\%), canned tuna (4.6\%), and $74.1 \%$ of tuna products were consumed 
by other countries.

Tuna has the highest composition of nutrients that have advantages for human body rather than other sources of animal protein such as chicken, pork and beef. Tuna has a high composition of protein ( $26 \mathrm{gr} / 100$ gr compared to $24 \mathrm{~g} / 100 \mathrm{gr}$ for chicken), potassium (24 g/100 gr compared to $380 \mathrm{mg} / 100 \mathrm{gr}$ for pork), unsaturated fatty acid $(147 \mathrm{mg} / 100 \mathrm{gr}$ compared to 0 $-0.2 \mathrm{mg} / 100 \mathrm{gr}$ for other animals) and Vitamin D (5 $\mu \mathrm{g} / 100 \mathrm{gr}$ compared to $0 / 100 \mathrm{mg}$ for other animals), and the usefulness are to keep our body healthy, to avoid high blood pressures, and to prevent the osteoporosis (OPRT, 2012).

Tuna shrimps, groupers and red snappers are highest value product of Indonesian seafood. Yellowfin Tuna and Skipjack are the second largest of Indonesian export values of fisheries after the shrimps. World market demand of Tuna is progressively increases, and people in the world are increasingly aware of consuming fishes. Exports of Indonesia fresh and frozen tunas gradually increase every year, especially to the Japanese and the United States markets. The export value of Indonesian tuna were $\mathbf{4 9 8 . 6}$ million dollars in 2011 and increased to 750 million dollars in 2012. The export of Indonesian tuna in 2011 reached 141,774 tonnes and 201,159 tonnes in 2012. It was higher than exports in 2010 (122,450 tonnes) (Ministry of Marine Affairs and Fisheries, 2012).

Tuna fishing activities have increased steadily due to hight demand of this commodity. It was affected to the stocks and decreased the weight and length per fish catched. This is indicates that wild tuna population have been overfishing. Western and Central Pacific Fisheries Commission (2013) mention that total production of tuna in the world catched by using pole-and-line fishing gear have decreased from 276,765 tonnes (2011) to 214,981 tonnes (in 2012). Miyake, et al. (2010) explains that over exploitation of Tuna resources particularly Bigeye, Skipjack and Yellowfin have been reach to the Maximum Sustainable Yield (MSY). It was same experience in subtropical tuna such as Albacore, Southern Bluefin, Pacific Bluefin and Atlantic Bluefin. Therefore, maintaining the tuna resources and environment is very important to keep sustain the resources.

Some experts are trying to farm tuna to address high demand of tuna and prevent intensive tuna fishing, but still debatable issue.The background is breeding tuna for farming purpose in some countries has not been successful yet. In other hand, fisheries industries are trying to raise baby tuna, which are caught from the wild into a desired size, called ranching or fattening. Definition of tuna farming is raising tuna in the big cages up to the size of consumption or market demand which starts from breeding and hatching. Longo (2011, p. 416) states that "tuna ranching or fattening is a form of intensive tuna production that tuna are captured and placed in feeding cages to rapidly increase weight, and specifically their fat content, until they are ready for slaughter".

Due to a significant improvement in tuna ranching industries and studies on breeding tuna to find a way out of demand and stock issues, some people are debating the positive and negative factors of tuna farming. Can it be argued that tuna farming harms the sustainability of the marine environment? If so, how to meet the demand for fish consumption especially the tuna market, where the price of tuna products is very expensive? These issues have led to a debate among experts concerning whether to halt or continue to develop tuna sea farming. This article will put forward good reasons why Indonesia should develop tuna farming to overcome the problem of overfishing and maintain the sustainability of the marine ecosystem.

\section{METHODOLOGY}

This paper describes about tuna farming development and its controversy. Data were collected by literature study on articles (journals, proceeding and online news) about tuna farming that have been published from some experts. These data were analyzed descriptively to understand the benefits and drawbacks of developing tuna farming.

\section{An Opportunity of Tuna Farming Development in Indonesia}

It has been debated that tuna farming has some negative impacts on the environment. Some environmentalists believe that the main problem with tuna farming is environmental issue because there will be some negative impacts on the marine ecosystem. Environmentalist who are concerned about tuna farming or advocate the protection of the environment are concerned about using of other fish species for feeding tuna such as sardines, herring, mackerel and squid because they will increase the effort to capture these fish in the ocean for tuna farming which will increase the pressure on the ecosystem. It is important to consider because tuna needs a lot of fish meal to increase the body weight. Tudela, et.al., (2004) mention that the Food Conversion Ratio (FCR) of Tuna is about 20:1, which means that a tuna needs $20 \mathrm{~kg}$ of feed to raise $1 \mathrm{~kg}$ of their weight.

Another important problem related to tuna farming to the ecosystem is the application of tuna ranching/fattening commonly rather than breeding tuna in the laboratory?? and then raising it in the pens. This is becoming a serious issues in the world because tuna ranching practices needs wild baby tuna, which affected to increase marine ecosystem pressure. Presently, tuna farming practices were raising the juveniles that are caught from the ocean instead of farming tuna from spawning area Ottolenghi (2008). 
It is worthy to be noted that tuna farming is one of the aquaculture practices that will reduce overfishing and maintain the availability of tuna products. Tuna farming could solve the problem of overfishing when breeding process can succeed in cages or laboratory scale. Otherwise, Fishing practices of baby tuna will be increased. Higuchi et al. (2013) suggest that it is important to breed tuna in farms to support tuna farming industries as well as to conserve tuna species. Aquaculture practice can controlled many variable such as production, fish size and harvesting time rather than fishing activities, which have influenced by natural factors such as the weather, tides, and fish movement.

Many studies have discussed about breeding technology for tuna farming. Japan and Australia has been develop the Spawning technology for tuna Indonesia, developing the breeding technology of tuna is need many years. Zulham, et al., (2013) explain that since 2003, Indonesian scientists need45 days to preserving the larvae of Yellofin Tuna. This is one of positive progress on knowledge development of tuna breeding. Several international organization such as Australian Center for International Agriculture Research (ACIAR) and Overseas Fishery Cooperation Foundation of Japan (OFCF) supported them. Study at Kinki University Japan revealed that Pacific Bluefin tuna can spawned in captivity with 1,100 eggs hatched and grew to $95 \mathrm{~cm}$ long and $14 \mathrm{~kg}$ in weight in 22 months (Sawada, et al., 2005).

Another reason for developing tuna farming is less impact on marine ecosystem. Zertuche-Gonzalez et. al., (2008) find out that tuna farming has a lower impact on the environment compared with other aquaculture practices for carnivorous species such as salmon farming. The reason is they use frozen and fresh fish for fish meal, which can get from residual or fish excretion rather than pellets which have waste large amounts of organic carbon. Based on those various studies, tuna farming technology show the positive progress in Indonesia. However, Indonesian scientists may improve the capacity on tuna farming through short course or study abroad.

\section{Tuna Farming: Lesson Learned From Several Countries}

Some experts argued that tuna farming is high cost and very expensive. They also concerned about the huge amount of capital for making tuna cages or pens. In case of tuna ranching in Ensenada Region of Northern Baja California, Mexico, need the cost about US\$ 80,000100,000 per cage to keep $1,500-2,000$ tuna they need the farm needs flat boats, 12-20 meter nets with mesh size $60-90 \mathrm{~mm}$, handrail, screw anchors, predator and freeboard nets. (Zertuche-González et al., 2008). Tuna farming operation by reproduction is different with tuna fattening operation, fattening the tuna needs a huge amount of additional operational costs. For example, The fattening the tuna needs a huge amount of funding especially for capturing the small tuna such as modern fishing vessels (US\$4.4-5.9 million), daily tug boat rental (US\$4,450), fuel, as well as small airplanes for detecting fish (Ottolenghi, 2008).

There is a potential loss of revenue of tuna farming industries, because interference from outside of the cages. Fish farming or ranching is more vulnerable to fish theft, diseases, water pollution, fish escaping and animals attacking. However, Dalton (2004) implies that fish aquaculture sometimes leads to outbreaks of diseases such as herpes viruses, as well as other animals attacking such as sea lion which can reduce the potential profit.

Economically, the expensive price of tuna products makes tuna export business quite lucrative. De

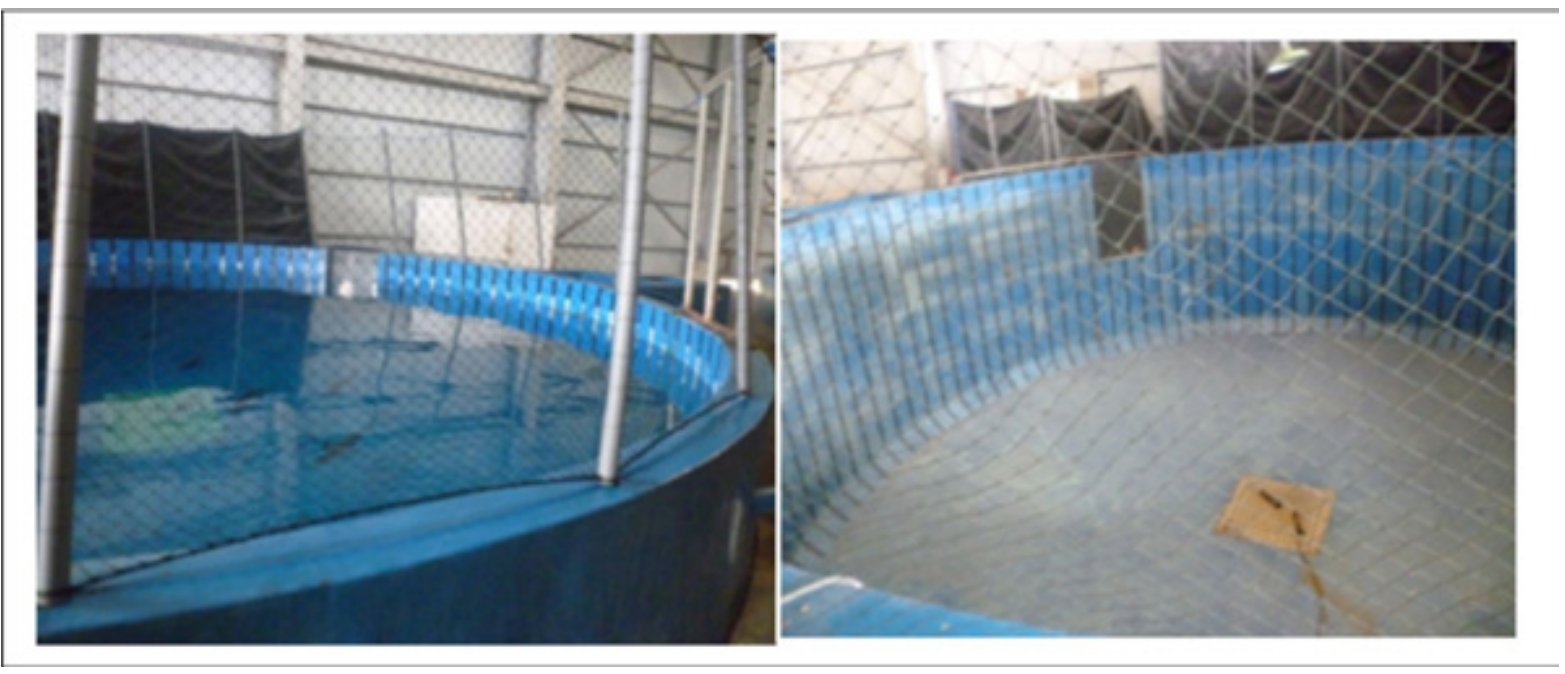

Figure 1. Fish Cages for Keeping Yellowfin Tuna for Breeding (Laboratory Scale) at Research Center for Marine Aquaculture, Gondol, Bali. 
Stefano \& Van Der Heijden (2007) state that tuna is the most valuable seafood product because of high price in international market. In Japan, about 489 pound tuna was sold to Japanese sushi restaurant for $\$ 1.76$ million in 2013, while in 2012 the price was only $\$ 736.000$ for a 593 pound tuna (Narula, 2014). Furthermore, the demand for tuna products constantly rises every year. In international side, there was a significant increase in tuna import value in US from USD 737.94 million in 2011 to 1.06 billion in 2012 for frozen loins and tuna steak products (FAO, 2014). However, it could potentially generate huge profits if tuna breeding could be conducted successfully. The high sales price of tuna would offset the high production cost such as cost of catching juveniles. Other study mentioned that In Sicilian, tuna ranching was conducted through capturing the baby tuna needs about $61 \%$ of the variable costs, whereas feeding activities, transportation and employee wages only needs $20 \%, 11 \%$ and $5 \%$ of the variable costs, respectively (De Stefano \& Van Der Heijden in 2007),

Another advantage of developing tuna farming is creating new employments opportunities and new industries. Employment would be established in some expertise such as tuna farming experts (farmers), scientists, administrators and supporting employees (security staffs, drivers). Moreover, new industries would be created to supply the farm such as ice production, cold storage facilities, milk fish aquaculture as fishmeal, and distribution businesses.

\section{Conclusion}

In conclusion, despite the claims by opponents of tuna farming that tuna farming has a negative impact on marine ecosystem and hight cost business. However, tuna farming is one of the technology that can reduce overfishing and gaining high surplus from export trade. In addition, the evidence above indicates that it is possible to breed tuna within some limitations. Some countries that implementing research on tuna breeding need refined and develop for tuna life cycle and its dynamics. In case of Indonesia, government mayprovide improve capacity of researchers through pursuing study, short course, expert exchange and research collaboration on tuna farming with other country. Those efforts may give positive impact on developing science and solve the problem on food demand.

\section{REFERENCES}

Dalton, R. (2004, September 30). Fishing for Trouble. Proquest Research Library, 431, 7008, pp. 502504.

De Stefano, V., \& Van Der Heijden, P. G. (2007). Bluefin Tuna Fishing and Ranching: A Difficult Managemen Problem. New Medit N.2/2007, 59-64.
Food and Agriculture Organization of the United Nations. (2014). Tuna Fisheries and Utilization. Retrieved September 2014, from Food and Agriculture Organization of the United Nations, for a world without hunger: http://www.fao.org/fishery/ topic/16917/en

Higuchi, K., Tanaka, Y., Eba, T., Nishi, A., Kumon, K., Nikaido, H., et al. (2013). High incidence of Death Due to Collision of Hatchery-Reared Pacific Bluefin Tuna Thunnus orientalis Juveniles in Sea Cages, as Revealed by Head and Spinal Injuries. Fish Sci (2013) 79, 111-117.

Longo, S. B. (2011). Global Sushi: The Political Economy of The Mediterranean Bluefin Tuna Fishery in the Modern Era. Journal of World-System Research, 403-427.

Ministry of Marine Affairs and Fisheries. (2012). Export Statistics of Fisheries Product by Commodity, Province and Port of Export 2012. Jakarta: Center of Data, Statistics, and Information, Secretariat General, Ministry of Marine Affairs and Fisheries.

Miyake, P. M., Guillotreau, P., Sun, C. H., \& Ishimura, G. (2010). Recent developments in the tuna industry. Stocks, Fisheries, Management, Processing, Trade and Markets. FAO Fisheries and Aquaculture Technical Paper. 543. ISSN 2070-7010. Food and Agriculture Organization of The United Nations.

Narula, S. K. (2014, Januari 5). Sushinomics: How Bluefin Tuna Became a Million-Dollar Fish. Retrieved September 2014, from http://www.theatlantic. com/international/archive/2014/01/ sushinomics-how-bluefin-tuna-became-amillion-dollar-fish/282826/.

Organization for the Promotion and Responsible Tuna Fisheries. (2012). Powerful Nutrition Values of Tunas. Retrieved September 2014, from http:// oprt.or.jp/eng/wp-content/uploads/2012/01/ OPRT_Powerfultunas.pdf

Organization for the Promotion of Responsible Tuna Fisheries. (n.d.). Global Tuna Supply \& Sashimi Tuna. Retrieved September 2014, from Organization for the Promotion of Responsible Tuna Fisheries: http:// oprt.or.jp/eng/data/global-tuna-supplysashimi-tuna/

Ottolenghi, F. (2008). Capture-based aquaculuture of bluefin tuna. In A. Lovatelli, \& P. F. Holthus, FAO Fisheries Technical Paper No 58 (pp. 169182). Rome: Food and Agriculture Organization of The United Nations.

Sawada, Y., Okada, T., Miyashita, S., Murata, O., \& Kumai, H. (2005). Completion of The Pacifik Bluefin Tuna Thunnus Orientalis life cylce. Aquaculture Research, 413-421. 
Tudela, S., \& Garcia, R. (2007, March 5). Tuna Farming in the Mediterranean: The Bluefin Tuna Stock at Stake. Retrieved August 2014, from (http://wwf. panda.org/what_we_do/where_we_work/ mediterranean/publications/?13510/TunaFarming-in-the-Mediterranean-the-bluefintuna-stock-at-stake).

Western and Central Pacific Fisheries Commission. (2013). Tuna Fishery Yearbook 2012. Noumea, New Caledonia: Western and Central Pacific Fisheries Commission.
Zertuche-Gonzalez, J. A., Rodriguez, J. G., Simanek, R. d., \& Yarish, C. (2008). Marine Science Assessment of Capture-Based Tuna (Thunnus orientalis). Connecticut: Department of Ecology \& Evolutionary Biology - Stamford, University of Connecticut.

Zulham, A., Yulisti, M., \& Muhartono, R. (2013). Opportunities for Development and Utilization of Tuna Farming Technology in Support on Fisheries Industrialization in Indonesia. Jakarta: Research Center for Marine and Fisheries Socioeconomics. 